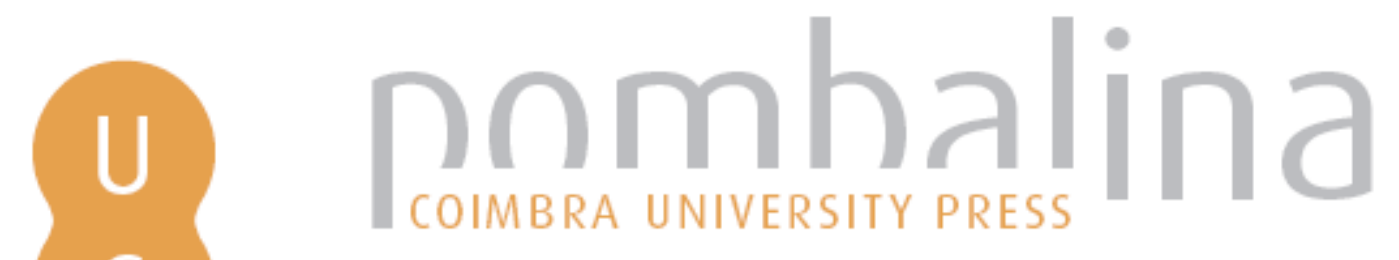

\title{
Sound/unsound: classroom identities and the sounds of English
}

\author{
Autor(es): $\quad$ Silver, Diana \\ Publicado por: Imprensa da Universidade de Coimbra \\ URL \\ persistente: $\quad$ URI:http://hdl.handle.net/10316.2/43211 \\ DOI: $\quad$ DOl:https://doi.org/10.14195/978-989-26-1483-0_4
}

Accessed : $\quad$ 26-Apr-2023 14:44:30

A navegação consulta e descarregamento dos títulos inseridos nas Bibliotecas Digitais UC Digitalis, UC Pombalina e UC Impactum, pressupõem a aceitação plena e sem reservas dos Termos e Condições de Uso destas Bibliotecas Digitais, disponíveis em https://digitalis.uc.pt/pt-pt/termos.

Conforme exposto nos referidos Termos e Condições de Uso, o descarregamento de títulos de acesso restrito requer uma licença válida de autorização devendo o utilizador aceder ao(s) documento(s) a partir de um endereço de IP da instituição detentora da supramencionada licença.

Ao utilizador é apenas permitido o descarregamento para uso pessoal, pelo que o emprego do(s) título(s) descarregado(s) para outro fim, designadamente comercial, carece de autorização do respetivo autor ou editor da obra.

Na medida em que todas as obras da UC Digitalis se encontram protegidas pelo Código do Direito de Autor e Direitos Conexos e demais legislação aplicável, toda a cópia, parcial ou total, deste documento, nos casos em que é legalmente admitida, deverá conter ou fazer-se acompanhar por este aviso.

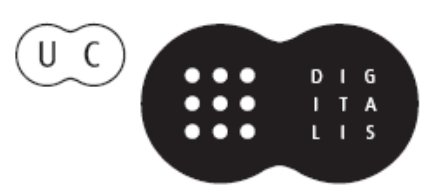




\section{IDENTITY(IES) A MULTICULTURAL AND MULTIDISCIPLINARY APPROACH}

\section{ANA PAULA ARNAUT \\ (ORG.)}

IMPRENSA DA UNIVERSIDADE DE COIMBRA

COIMBRA UNIVERSITY PRESS 


\title{
SOUND/ UNSOUND：CLASSROOM IDENTITIES
} AND THE SOUNDS OF ENGLISH

Diana Silver

University of Coimbra

\begin{abstract}
Can English pronunciation be taught, is it being taught, and how does producing oral English impinge on students' identities? This paper begins by considering some recent controversy around the teaching of English pronunciation, highlighting the intensely personal nature of the skill. It continues by looking at results from a small survey of teachers in public and private schools in the Central region of Portugal, examining their attitudes and practice. We see that while the majority claim to do some pronunciation work weekly, a large minority devote very little time to it, and that what deters them most are curricular pressures and the lack of support from class materials. Finally, based on interviews with university students, including some from other countries, we look at their attitudes to speaking English, particularly to pronunciation, how their classroom experiences fit with their lives outside school, and to what extent English speaking is part of their shifting identities. Over half reported that they had done very little or no oral production or pronunciation work in their English classes (in theory precisely the 'safe space'
\end{abstract}


where such new phonological identities can be rehearsed), and that this had hindered their development of their identities as English speakers. Released from the school classroom, however, most of these university students felt freer to take the risks of speaking English, some even playfully trying out new identities in social settings.

Keywords: Pronunciation of English, Teaching Pronunciation, Pronunciation and Identity

\section{Introduction}

This paper begins by considering some recent controversy around the teaching of English pronunciation, highlighting the intensely personal nature of the skill, and goes on to look at what teachers are currently doing with pronunciation in Portuguese schools in the Central region.

I work with university students, many of them recent school leavers, and some of them from other countries, and I move on to consider their attitudes to speaking English, particularly to pronunciation, how their classroom experiences fit with their lives outside school, and to what extent English speaking is part of their shifting identities.

Theoretically, I have adopted a sociocultural approach to language learning, seeing learners' identities, as Ros i Solé (2008: 204) puts it, as "culturally complex and dynamic, fluid, multiple and changing". This is particularly relevant in the case of young people, such as the first year University students that I interviewed. I follow Joseph (in Llamas and Watt, 2010: 9) in believing "people's choice of language, and ways of speaking, do not simply reflect who they are, but make them who they are, or more precisely, allow them to make themselves". 


\section{Teaching pronunciation: the controversy}

That pronunciation has been a neglected area of English teaching is well recognised. The neglect seems surprising, however, given the results of Jenkins' research (2000), which point to the "almost negligible role of incorrect grammar as cause of miscommunication. This is in marked contrast with the importance most coursebooks give to grammar, and the amount of class time most of us as teachers dedicate to this area" (Walker, 2010: 26). But is this neglect of pronunciation in any way justifiable? - is it to some extent a natural and inevitable state of affairs, or is it something that needs to be remedied? This 'question that simply will not go away' was raised in typically lively style in Scott Thornbury's blog An $A-Z$ of ELT (posted 1/8/2010). Thornbury himself is sceptical about the value of pronunciation teaching: after referring to findings supporting his scepticism, however, he remains unsure about how to react:

Now, is this bad news (we can't do much to help our learners achieve acceptable standards of pronunciation)? Or is it good news (we don't have to teach pronunciation, and can spend the time saved on more important stuff)?

As expected, Thornbury's blog aroused plenty of controversy among teachers and some researchers worldwide. ALiCe_M (2010:6) wrote that "correcting the sounds somehow feels more personal than correcting a grammar error". The eminent Stephen Krashen referred to his own paper (1997), and conjectured, on what he admitted is "flimsy evidence", that "accurate pronunciation in a second language, even in adults, is acquired rapidly and very well. We simply do not use our best accents because we feel silly".

Other writers, such as Setter and Jenkins (2005), found that pronunciation has been "universally considered to be a 'difficult' 
aspect of an L2 to teach, probably the most difficult". This may be because L1 pronunciation habits are formed early. A group of Australian teachers found that

by far the majority of pronunciation problems stem ... from cognitive causes. ... Learners need to 'unlearn' the concepts they have held since babyhood for ... sounds, and replace them with the similar but different concepts needed to speak English. (Teaching pronunciation, 2001: 20)

Furthermore, since pronunciation projects our social and ethnic identity, L2 learners may be "subconsciously resistant to change, despite superficially wanting a 'native-like' accent". A major problem, they found, was the subconscious level at which pronunciation operates, which makes it difficult to work on. Daniels (1997: 82) gives a powerful image of this resistance to "the development of a new ego", presenting our accents as:

a sort of umbilical cord which ties us to our mother. Whenever we speak an L2 we cut that cord, perhaps unconsciously afraid of not being able to tie it up again when we revert to L1... A possible way of avoiding the cut is to continue using the sounds, the rhythm and the intonation of our mother tongue while pretending to speak L2.

Most teachers will have experienced such resistance, particularly perhaps on the part of teenage boys anxious about their emerging adult selves. As Walker says (2010: 66), "adolescents are often struggling to define their own mother-tongue identity, especially in front of their peers. This would not appear to be the best moment to ask them to take on a new identity through pronunciation". Could the comparative confidence of many young teenage girl students 
in producing L2 sounds, which some teachers have noticed, reflect their relative confidence in their own identity, and a corresponding willingness to 'try on' other identities as presented in the sounds of a language?

\section{'Spending time on more important stuff'? Pronunciation teaching in Portugal}

We have seen that whatever else they may disagree on, few dispute that teaching and learning pronunciation is difficult; what correspondents worldwide (many of them Brazilian) on Thornbury's (2010) blog say, is that they continue to do it, despite the difficulties. Is this determination also seen in Portugal? - what aspects of pronunciation are focused on, why, and how frequently? This section looks at the results of a small survey carried out in 2011/2012 in the Central region by means of a questionnaire, respondents being 14 state-school teachers, Portuguese nationals, and, for purposes of comparison, 7 British language-school teachers. In addition to the questionnaire, I conducted informal interviews with 7 teacher-trainers from schools in the Central region. Results of answers to a few of the survey questions are shown here, with some comments on each set.

\begin{tabular}{|l|c|c|}
\hline \multicolumn{1}{|c|}{ Table 1 } & \multicolumn{2}{c|}{ Number of replies } \\
\hline $\begin{array}{l}\text { How often do you spend any time in class } \\
\text { on the pronunciation of English? }\end{array}$ & $\begin{array}{c}\text { State school } \\
\text { (total 14) }\end{array}$ & $\begin{array}{c}\text { Language school } \\
\text { (total 7) }\end{array}$ \\
\hline At least once a week & 5 & 6 \\
\hline Every 2 -3 weeks & 2 & 0 \\
\hline Once a month, approx. & 3 & 0 \\
\hline Rarely & 4 & 1 \\
\hline
\end{tabular}


In Table 1, focusing on the teaching of pronunciation in class on a regular basis, the majority (62\%) of respondents here have some pronunciation work weekly, with language-school teachers tending to devote more time to it, but $38 \%$ do phonological work once a month or less.

\begin{tabular}{|l|c|c|}
\hline \multicolumn{1}{|c|}{ Table 2 } & \multicolumn{2}{c|}{ Number of replies } \\
\hline $\begin{array}{l}\text { If 'once a month' or' rarely', choose 1 or 2 } \\
\text { of the following: I don't teach or practice } \\
\text { pronunciation more often because - }\end{array}$ & $\begin{array}{c}\text { State school } \\
\text { (total 7) }\end{array}$ & $\begin{array}{c}\text { Language school } \\
\text { (total 1) }\end{array}$ \\
\hline students' pronunciation is good already & 3 & 1 \\
\hline uncertain what model to present & 3 & 0 \\
\hline $\begin{array}{l}\text { too many other matters to deal with in } \\
\text { class }\end{array}$ & 6 & 0 \\
\hline coursebooks don't deal with it & 5 & 0 \\
\hline techniques are old-fashioned & 2 & 0 \\
\hline students uninterested & 0 & 1 \\
\hline
\end{tabular}

In Table 2, results show that what deters teachers from devoting valuable class time to pronunciation are curricular pressures and the lack of support from class materials, rather than satisfaction with the status quo.

\begin{tabular}{|l|c|c|}
\hline \multicolumn{1}{|c|}{ Table 3 } & \multicolumn{2}{c|}{ Number of replies } \\
\hline $\begin{array}{l}\text { If 'weekly' or 'every 2 or 3 weeks', what } \\
\text { areas of pronunciation do you focus on? }\end{array}$ & $\begin{array}{c}\text { State school } \\
\text { (total 7) }\end{array}$ & $\begin{array}{c}\text { Language school } \\
\text { (total 6) }\end{array}$ \\
\hline Phonemes & 6 & 4 \\
\hline Prosodic features & 7 & 5 \\
\hline Linking sounds in connected speech & 4 & 4 \\
\hline Relation of sounds to written forms & 7 & 3 \\
\hline
\end{tabular}


From Table 3 it seems that a very high percentage of teachers focus on features (e.g. intonation) that extend beyond single phonemes or syllables. Many teachers obviously realise that this is a necessary and agreeable area for class work, while not neglecting individual sounds.

\begin{tabular}{|l|c|c|}
\hline \multicolumn{1}{|c|}{ Table 4 } & \multicolumn{2}{c|}{ Number of replies } \\
\hline $\begin{array}{l}\text { What aspects of pronunciation do your } \\
\text { students have most problems with? }\end{array}$ & $\begin{array}{c}\text { State school } \\
\text { (total 14) }\end{array}$ & $\begin{array}{c}\text { Language school } \\
\text { (total 7) }\end{array}$ \\
\hline Recognising/ producing sounds & 7 & 3 \\
\hline Prosodic features & 10 & 5 \\
\hline Sound/ spelling relationship & 12 & 4 \\
\hline Others (inserted): linking, weak forms & 0 & 1 \\
\hline
\end{tabular}

Table 4 shows that the major difficulty for students, as seen by these Portuguese English teachers, is the lack of a close relationship between sound and spelling. This is clearly related to the classroom activity preferred by this group, which was reading aloud.

Having shown something of what local teachers allege about their practice, I now consider how some students perceive their school experience, how it relates to their English speaking outside school and to their identities as English speakers.

\section{'Performing identity with words' - and sounds: what students say about their English use}

This quote from Makoni and Pennycook (2007: 110) highlights the role of language in the construction of identity, and vice versa - on language as 'a semiotic restructuring as a claim to a particular 
identity'. Here I present results from the interviews I conducted with students, together with some comments.

In 2013 I conducted semi-structured interviews with 14 students at the University of Coimbra. Their year, subject and country of origin is shown in table 5. My aim was to find out, in so as far as I could with the methods I used, students' experiences and feelings about their use of spoken English within and outside the classroom. For this I tried to focus on students in the $1^{\text {st }}$ and $2^{\text {nd }}$ years of University, when their memories of school might be relatively fresh.

\begin{tabular}{|l|l|c|}
\hline \multicolumn{2}{|c|}{ Table 5 - Interviewees } & No of students \\
\hline \multirow{5}{*}{ Subjects studied } & Tourism & 4 \\
\cline { 2 - 3 } & Law & 3 \\
\cline { 2 - 3 } & Portuguese & 3 \\
\cline { 2 - 3 } & Geography & 2 \\
\cline { 2 - 3 } & Archaeology/History & 1 \\
\cline { 2 - 3 } & European Studies & 1 \\
\hline \multirow{5}{*}{ Nationality/Home University } & Portuguese & 7 \\
\cline { 2 - 3 } & Brazilian & 3 \\
\cline { 2 - 3 } & Czech & 2 \\
\cline { 2 - 3 } & Bulgarian & 2 \\
\hline \multirow{5}{*}{ Students' years at University } & 1st & 7 \\
\cline { 2 - 3 } & 2nd & 5 \\
\cline { 2 - 3 } & 3rd & 2 \\
\hline \multirow{5}{*}{ Language of interview } & English & 6 \\
\cline { 2 - 3 } & Portuguese & \\
\hline
\end{tabular}

Summarising briefly some results from the interviews: in terms of their school experience, over half of the students reported that that they had done very little or no speaking or work on pronunciation in their English classes (a contrast to what our local school teachers said that they do). Unsurprisingly, a factor that hindered about half the students in their development as English speakers was exactly this 
lack of opportunity to practice speaking in the classroom, though one also mentioned her teacher's "strange pronunciation".

With regard to feelings about speaking English outside the classroom, many students said they felt more at ease outside than inside, when they might be in the presence of a judgmental teacher. Morgan (1997: 432) sees the English classroom as a social environment formed by Gidden's 'reflexive project of the self'; Jenks (2013: 166) asks how students can create relevant identities, and how their use of English affects these identities. It is clear that this creation can be encouraged by the teacher, but can just as easily (or indeed more easily) be hindered, as these students suggest.

On their feelings about speaking English in general, and about their pronunciation in particular, several respondents expressed some confidence in their English, though 2 said that their feelings depended on the situation ("surprises are more difficult", said one). Feelings of dissatisfaction, or even shame and embarrassment, surfaced from over a third of the students. One talked about her "Stone Age English", another said "I have it in the head but it doesn't come out right", while another cited embarrassment as the reason why he doesn't like speaking English to girls. With pronunciation, nearly half expressed dissatisfaction: "It's horrible", said one (it wasn't horrible, to me); "It worries me a lot", said another (quite unnecessarily in her case, I thought), while another said she became aware of her pronunciation 'errors' when speaking with others. These last few comments point to Johnstone's view (in Llamas and Watt, 2010: 31) of pronunciation as an evocation or creation of a social identity - in these cases, the students may be rejecting the identity they suspect they are creating that of a fumbling, ineffective, uncool, 'unsexy' English speaker.

When asked if speaking English was a significant part of their identity, it was interesting to see that most European students were more or less positive, with comments ranging from a weak "sort of" to a decisive "Certainly - and I want to live in England". The 
three Brazilians, on the other hand, didn't feel it was part of their identity at all, but this is not surprising given that their English was at elementary level.

I also asked students if they felt they could assume a different identity when they spoke English; most said no, but there were some surprising responses. Two, quite proficient speakers, exchange students, said they liked to assume different national identities in English, being able to 'pass' as for example, Russian or Italian, by 'putting on accents' in social situations with other foreign students: in effect, they were playing with different sounds of English. Another student admitted "I feel me, but a bit more confident"; another said she could imagine she was a Londoner, and then imagine different alternative identities for herself, whereas a Czech student said that, compared to Czech, "English feels more polite, ... so I feel more polite, slower".

In conclusion: Data from local teachers indicates their willingness to focus on some aspects of English speaking in the classroom, but for many of these students, even those who spoke relatively fluently, their classroom speaking experience was inadequate or even undermining of their identities. It is not surprising that, released from the school classroom, most of these university students felt freer to take the risks of speaking English, and even sometimes of trying out new identities.

If there was anything surprising in what I found, it would be this apparent mismatch between what these teachers said they did and the reported experience of students. However, questionnaire responses are often unreliable; in addition, these teachers and these students were not necessarily from the same region or even the same continent: we need a closer comparison before we can draw useful conclusions. Nevertheless, it is clear that some teachers still need convincing of the value of a sympathetic focus on oral work in class.

I shall end with two small personal narratives showing examples of the role of pronunciation in the affirmation of identity. Clara, 
a Portuguese student, recalled how, as a child on holiday in the Algarve, her English pronunciation had been ridiculed by older, foreign children: the 'users of the dominant discourse' in the Algarve, namely the English-speakers, had denied 'audibility' to Clara, to use Miller's term (Pavlenko and Blackledge, 2004: 291). But, rather than undermining her confidence, this had become an incentive for her, she said, to develop her identity as an English speaker.

As Joseph says (2004: 20), identity can fairly be seen as 'a distinct and major function of a language'. Speaking for myself, I recently had my identity as a reliable informant on local topography implicitly questioned when I was asked directions, near here, by a couple of Portuguese tourists. I had hardly started explaining in Portuguese when one exclaimed that I wasn't "from here". I explained that no, I wasn't, but that I had lived here for many years and so could easily give them the directions they wanted, and proceeded to do so. However, although the tourists evidently understood the content of what I was saying, I could see I was not being given credence, simply because my simple directions were being produced with non-native pronunciation, and I strongly suspected that the tourists would soon find someone else more 'reliable', or at least less foreign-sounding, to ask. My sense of identity as a 'local' and as a reasonably competent foreign speaker of Portuguese had been called into question, an experience I didn't like. I was reminded of Joseph's observation (2004: 24) that we make instant judgements when we hear somebody speak, and infer 'whether we consider the person to be intelligent, likeable, trustworthy and so on' (I'm not sure which of those qualities I was found to be lacking on that occasion). I was also reminded of Block's 'perhaps exaggerated sense of identity as an acceptable interlocutor' when his proficient responses in the local language, Catalan, were ignored in favour of Castilian, more expected of a foreigner in Spain (Block and Cameron, 2002: 131). In both Block's and my experiences, simple communication - here 
transferral of information - was not the only thing that was going on. For all the parties, our identities - in these cases, our identities as trustworthy informants, as local residents, as speakers of first and foreign languages - were crucial players in the interaction game, as indeed our identities always are.

\section{References}

Block, D. and D. Cameron (eds.) (2002). Globalization and Language Teaching. London: Routledge.

Daniels, H. (1998). "Psycholinguistic, psycho-social and procedural factors in the acquisition of authentic L2 pronunciation". In: McLean, A. (ed.) 1997. SIG Selections 1997 Special Interests in ELT, pp. 80-85.

Jenks, C. (2013). "Your pronunciation and your accent is very excellent": orientations of identity during compliment sequences in English as a lingua franca encounters". In: Language and Intercultural Communication 13:2, pp. 165-181.

Joseph, J. (2004). Language and Identity: National, Ethnic, Religious. Basingstoke: Palgrave Macmillan.

Krashen, S. (1997). "A conjecture on accent in a second language". In: . Lengyel, Z., Navracsics, J.; Simon, O. (eds.) Applied Linguistic Studies in Central Europe, vol 1. Department of Applied Linguistics, University of Veszprem, Hungary.

Llamas, C. and D. Watt (eds.) (2010). Language and Identities. Edinburgh: Edinburgh University. Press.

Makoni, S. and Pennycook, A. (eds.) (2007). Disinventing and Reconstituitng Languages. Clevedon: Multilingual Matters.

Morgan, B. (1997) "Identity and intonation: linking dynamic processes in the ESL classroom". In: TESOL Quarterly 31:3, pp. 431-450.

Ros i Solé, C. (2007). "Language learners' sociocultural positions in L2: a narrative approach”. In: Language and Intercultural Communication 7:3, pp. 203-216.

Setter, J. and Jenkins, J. (2005). "State-of-the-art review article". In: Language Teaching 3, pp. 1-17

Teaching Pronunciation, a Handbook for Teachers and Trainers: Three Frameworks for an Integrated Approach (2001). Sydney: New South Wales Department of Education and Training. Consulted 11/6/2012 at http://helenfraser.com.au/ downloads/HF\%20Handbook.pdf>

Thornbury, S. (2010). "P is for pronunciation". In: An A-Z of ELT. Consulted 1/10/2011 at <http://scottthornbury.wordpress.com/2010/08/01/p-is-for-pronunciation/>

Walker, R. (2010). Teaching the Pronunciation of English as a Lingua Franca. Oxford:

Oxford U. Press. 